\title{
Indikator Fiscal Impulse untuk Pengukuran Stance Kebijakan Fiskal
}

\author{
Decymus $^{1}$ \\ Diana Permatasari
}

\section{Pendahuluan}

Kajian terhadap operasi keuangan pemerintah atau saldo (surplus / defisit) anggaran sering digunakan untuk melihat arah kebijakan fiskal, apakah bersifat ekspansif atau kontraktif terhadap perekonomian pada suatu periode tertentu. Lebih jauh, kajian tersebut dimaksudkan untuk melihat apakah ada upaya dari pemerintah untuk mempengaruhi permintaan agregat agar bergerak menuju tingkat output yang diinginkan. Namun, berbagai penelitian membuktikan bahwa angka operasi keuangan atau saldo anggaran saja ternyata tidak cukup untuk menjelaskan arah kebijakan fiskal. ${ }^{2}$

Oleh karena itu, perlu ada indikator lain untuk mengatasi kelemahan tersebut di atas. Indikator dimaksud adalah Fiscal Impulse yang dikembangkan oleh German Council of Economic Expert (GCEE) dan digambarkan secara detail oleh Dernberg (1975). Indikator ini kemudian dikembangkan lebih lanjut oleh IMF dan oleh beberapa bank sentral di dunia dipakai sebagai alat (tools) terutama untuk melakukan assessment terhadap hubungan kebijakan fiskal dengan perekonomian.

Sebagai sebuah alat, indikator fiscal impulse masih memiliki kelemahan yaitu bahwa indikator ini hanya mampu menjelaskan sampai pada apakah stance kebijakan fiskal pada suatu periode bersifat kontraktif atau ekspansif terhadap perekonomian, namun tidak bisa menjawab berapa besar dampak atau efek multiplier dari operasi keuangan pemerintah tersebut terhadap perekonomian. Pengukuran dampak atau efek multiplier operasi keuangan pemerintah membutuhkan alat bantu lain yaitu berupa model makroekonomi seperti Macroeconometric Model of Singapore (MMS), New Zealand Treasury Model (NZTM), dan MODBI di Bank Indonesia. ${ }^{3}$

1 Peneliti Ekonomi dan Asisten Peneliti Ekonomi di Bagian Analisis dan Perencanaan Kebijakan, Bank Indonesia.

2 Clark, Tom and Andrew Dilnot, Measuring the UK Fiscal Stance since the Second World War, The Institute for Fiscal Studies, Briefing Note No. 26

3 Perhitungan dampak multiplier operasi keuangan pemerintah terhadap perekonomian secara sederhana dapat dimulai dari fungsi consumsi yaitu bahwa pendapatan siap pakai yang lebih tinggi menyebabkan konsumsi yang lebih tinggi. Setiap rupiah belanja domestik pemerintah akan menjadi pendapatan bagi suatu pelaku ekonomi domestik, yang kemudian oleh pelaku ekonomi domestik tersebut dibelanjakan untuk membiayai konsumsinya. Proses yang sama akan berlanjut dari 


\section{Aspek Teoritis Indikator Fiscal Impulse (FI)}

Indikator fiscal impulse pada dasarnya menggambarkan perkembangan besaran fiskal (surplus / defisit anggaran) yang telah dikonfrontasikan dengan perkembangan PDB agar kesimpulan yang dihasilkan benar-benar mencerminkan stance kebijakan fiskal dalam suatu periode tertentu, apakah bersifat kontraktif atau ekspansif terhadap perekonomian. Secara matematis, indikator fiscal impulse tersebut dijabarkan dalam bentuk persamaan sebagai berikut: $^{4}$

$$
\mathrm{FI}=-\Delta \mathrm{B}-\mathrm{g}_{0} \Delta \mathrm{Y}^{\mathrm{P}}+\mathrm{t}_{0} \Delta \mathrm{Y},
$$

dimana :

FI $=$ fiscal impulse

$\mathrm{T}=$ penerimaan negara

$\mathrm{G} \quad=$ belanja negara

$\Delta \mathrm{B}=$ perubahan defisit $/$ surplus $\left(\mathrm{B}_{\mathrm{t}}-\mathrm{B}_{\mathrm{t}-1}\right)$ dimana $\mathrm{B}=\mathrm{T}-\mathrm{G}$

$\mathrm{g}_{0}=\mathrm{G}_{0} / \mathrm{Y}_{0}$, rasio belanja negara pada tahun dasar

$\mathrm{t}_{0} \quad=\mathrm{T}_{0} / \mathrm{Y}_{0^{\prime}}$ rasio penerimaan negara pada tahun dasar

$\Delta \mathrm{Y}^{\mathrm{P}}=$ perubahan PDB harga berlaku potensial $\left(\mathrm{Y}_{\mathrm{t}}^{\mathrm{P}}-\mathrm{Y}_{\mathrm{t}-1}^{\mathrm{P}}\right)$

$\Delta \mathrm{Y}=$ perubahan PDB harga berlaku $\left(\mathrm{Y}_{\mathrm{t}}-\mathrm{Y}_{\mathrm{t}-1}\right)$

Komponen pertama dalam persamaan tersebut (DB) menunjukkan perubahan actual budget, sedangkan komponen kedua dan ketiga $\left(-\mathrm{g}_{0} \Delta \mathrm{Y}^{\mathrm{P}}+\mathrm{t}_{0} \Delta \mathrm{Y}\right)$ menunjukkan perubahan cyclically neutral budget. Secara sederhana, actual budget dapat diartikan sebagai selisih antara pendapatan dan belanja negara yang ditetapkan oleh pemerintah, sedangkan cyclically neutral budget dapat diartikan sebagai selisih antara potensi pendapatan dan belanja negara yang dapat digarap oleh pemerintah sesuai perkembangan ekonomi (automatic stabilizer). Yang dimaksud pendapatan negara adalah pendapatan negara yang mengkontraksi perekonomian domestik, sedangkan belanja negara adalah belanja negara yang menginjeksi perekonomian domestik.

Persamaan di atas menjelaskan bahwa fiscal impulse dihitung dari perbedaan antara perubahan actual budget dari periode tahun dasarnya dengan perubahan cyclically neutral

\footnotetext{
suatu pelaku ekonomi domestik ke pelaku ekonomi domestik lainnya, dst. Secara agregat, kenaikan Rp1 belanja pemerintah -melalui proses multiplier - akan menyebabkan kenaikan lebih dari Rp1 pendapatan nasional (Lihat Mankiw, 2000). Secara matematis dapat ditulis:

4 Lihat Heller, Peter and others, A Review of the Fiscal Impulse Measure, IMF Occasional Paper No. 44 (May 1986).
} 
budget pada kedua periode tersebut. Tahun dasar adalah suatu tahun dimana PDB aktual secara kasar diasumsikan sama dengan PDB potensial. ${ }^{5}$ Cyclically neutral budget diturunkan dari actual budget pada tahun dasar dengan mengasumsikan bahwa pendapatan negara bersifat unitary elastic terhadap PDB aktual dan belanja negara bersifat unitary elastic terhadap PDB potensial. ${ }^{6}$ Dengan demikian, belanja negara akan bersifat cyclically neutral jika ia meningkat secara proporsional dengan peningkatan PDB potensial; hal yang sama berlaku untuk perubahan pendapatan negara terhadap perubahan PDB aktual.

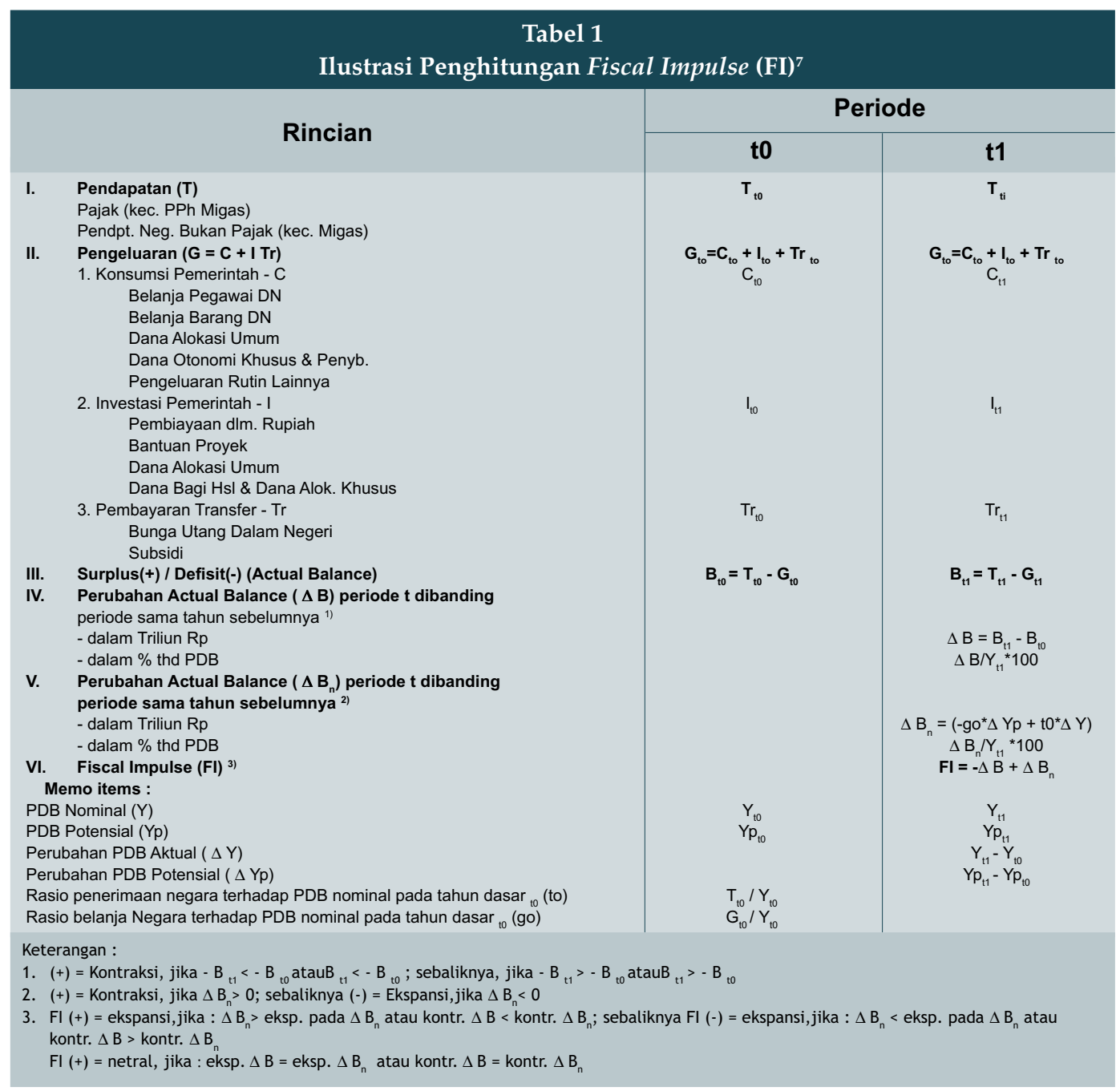

5 Karena alasan praktis, tahun dasar ditetapkan secara rolling base year dalam arti bahwa tahun lalu ditetapkan sebagai tahun dasar untuk mengukur stance kebijakan fiskal tahun ini.

6 PDB potensial dihitung dengan menggunakan metode Hodrick-Prescott Filter.

7 Decymus dan Dian Prima S., Manual Analisis Fiskal di Bank Indonesia, Bagian Analisis Perencanaan Kebijakan, Bank Indonesia, 2003. 
Dengan konsep di atas, jika tidak terjadi perubahan kebijakan fiskal atau tidak ada diskresi pemerintah, perubahan actual budget akan sama dengan perubahan cyclically neutral budget, sehingga secara matematis angka fiscal impulse akan nol. Artinya, stance kebijakan fiskal bersifat netral. Sementara itu, jika perubahan surplus actual budget lebih besar dari perubahan surplus cyclically neutral budget atau perubahan defisit actual budget lebih kecil dari perubahan defisit cyclically neutral budget, maka angka fiscal impulse akan negatif. Artinya, pemerintah melakukan kontraksi fiskal dalam jumlah yang lebih besar dari kemampuan potensial perekonomian atau pemerintah melakukan ekspansi fiskal dalam jumlah yang lebih kecil dari kebutuhan potensial perekonomian. Hal yang sama berlaku sebaliknya, jika perubahan surplus actual budget lebih kecil dari perubahan surplus cyclically neutral budget atau perubahan defisit actual budget lebih besar dari perubahan defisit cyclically neutral budget, maka angka fiskal impulse akan positif. Artinya, pemerintah melakukan kontraksi fiskal dalam jumlah yang lebih kecil dari kemampuan potensial perekonomian atau pemerintah melakukan ekspansi fiskal dalam jumlah yang lebih besar dari kebutuhan potensial perekonomian.

Berkaitan dengan stance kebijakan fiskal yang ditempuh pemerintah, Alesina dan Perotti (1995) mengkategorikan signifikansi stance kebijakan tersebut terhadap perekonomian dalam beberapa skala sebagai berikut: ${ }^{8}$

Sangat longgar : jika FI lebih kecil dari -1,5\% dari PDB

Longgar : jika FI antara $-0,5 \%$ dan $-1,5 \%$ dari PDB

Netral : jika FI antara $-0,5 \%$ dan $0,5 \%$ dari PDB

Ketat : jika FI antara 0,5 dan $1,5 \%$ dari PDB

Sangat Ketat : jika FI lebih besar dari 1,5\% dari PDB

\section{Metode Pengolahan Data}

Pengukuran fiscal impulse di Indonesia dilakukan dengan menggunakan data Operasi Keuangan Pemerintah Pusat (Central Government) dari tahun 1993 sampai dengan 2003. Untuk mengakomodir perubahan sistem tahun anggaran sejak tahun 2001, maka data historis triwulanan APBN sampai dengan tahun anggaran 2000 yang semula dalam bentuk tahun fiskal dirobah menjadi tahun kalender.

8 Philip, Renee dan John Janssen, Indikator of Fiscal Impulse for New Zealand, New Zealand Treasury Working Paper 02/30, Desember 2002. Alesina dan Perotti menggunakan budget balance sebagai indikator fiscal impulse, sehingga positif mengindikasikan surplus, negatif mengindikasikan defisit. 
Data-data APBN tersebut kemudian diolah untuk mengukur fiscal impulse Indonesia dengan metode sebagai berikut:

1. Pendapatan negara $(\mathrm{T})$ mencakup semua pendapatan negara di luar penerimaan migas, pajak migas dan hibah. Penerimaan migas, pajak migas dan hibah dikeluarkan dari perhitungan karena dari sisi anggaran negara tidak bersifat mengkontraksi perekonomian.

2. Belanja negara $(\mathrm{G})$ mencakup belanja pegawai, belanja barang, bunga utang dalam negeri, bunga utang dalam negeri, subsidi, pengeluaran rutin lainnya, anggaran pembangunan dan anggaran untuk daerah. ${ }^{9}$ Komponen belanja lainnya seperti pembayaran bunga utang luar negeri, belanja pegawai luar negeri dan barang luar negeri dikeluarkan dari perhitungan karena tidak bersifat menginjeksi perekonomian.

3. Tahun dasar menggunakan metode rolling base year yaitu angka suatu triwulan dibandingkan dengan triwulan yang sama pada tahun sebelumnya, sedangkan perhitungan tahunan didapat dengan membandingkan angka suatu tahun dengan tahun sebelumnya. Teknik ini berguna untuk menetralkan faktor musiman dan siklikal baik anggaran maupun PDB.

4. Dengan menggunakan metode tahun dasar seperti pada butir 3, maka analisis FI ditujukan untuk melihat stance kebijakan fiskal pada suatu triwulan dibanding triwulan yang sama pada tahun sebelumnya atau suatu tahun dibanding tahun sebelumnya.

\section{Pengukuran Fiscal Impulse Indonesia}

Pengukuran fiscal impulse Indonesia dengan menggunakan data APBN yang telah diolah dengan menggunakan metode tersebut di atas memberikan gambaran sebagai berikut:

1. Pada periode sebelum krisis 1998, pertumbuhan ekonomi tercatat cukup tinggi sebelum akhirnya mulai menurun pada tahun 1997. Memanfaatkan momentum pertumbuhan tersebut, pemerintah terlihat menjalankan stance kebijakan fiskal yang kontraktif dibandingkan tahun sebelumnya, meskipun magnitude-nya cenderung menurun menuju tahun 1996 (Grafik 1). Stance kebijakan yang bersifat kontraktif tersebut dilakukan pemerintah melalui kebijakan pengendalian belanja negara.

9 Dampak injeksi fiskal terhadap permintaan agregat dalam bentuk pembayaran bunga utang dalam negeri masih dipertanyakan karena belanja pemerintah dalam bentuk ini pada dasarnya masih merupakan bail-out pemerintah untuk menutup kerugian sektor perbankan. Sebagai informasi, Monetary Authority of Singapore (MAS) dan beberapa negara tidak memasukkan pengeluaran pemerintah dalam rangka menolong perusahaan negara yang akan bangkrut (bail-out) dalam perhitungan FI. 


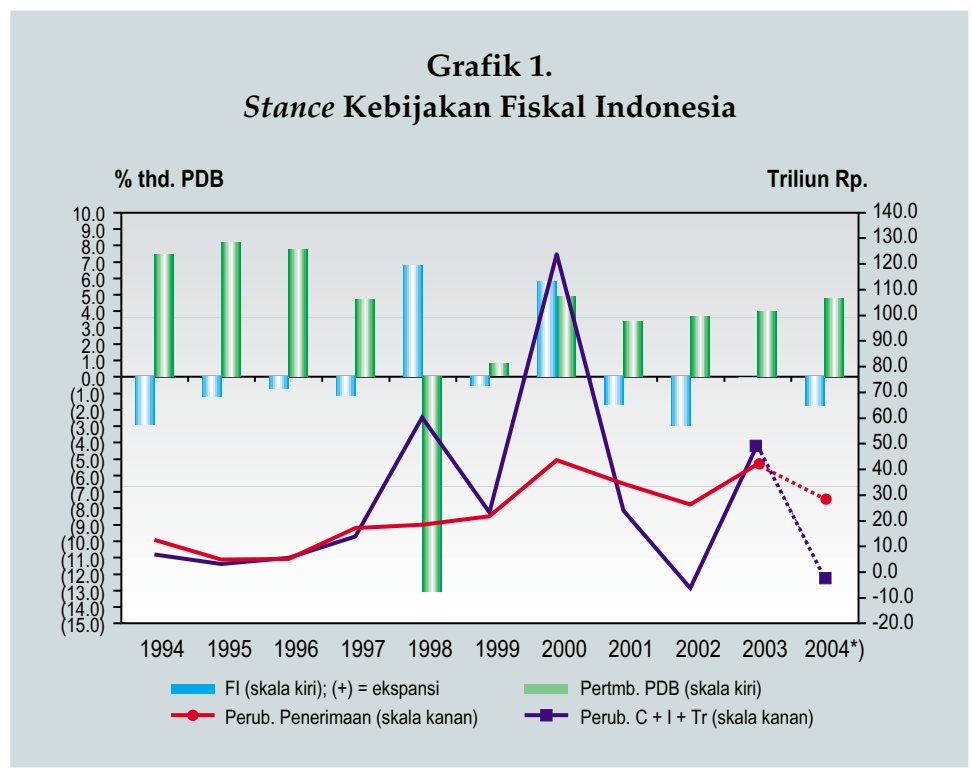

2. Pada saat krisis 1998, pertumbuhan ekonomi berbalik menjadi negatif yang cukup tajam sehingga pemerintah menerapkan stance kebijakan yang sangat ekspansif untuk mencegah krisis yang semakin dalam. Kebijakan tersebut dijalankan pemerintah melalui peningkatan yang cukup tajam pada pos belanja negara, khususnya dalam bentuk subsidi dan jaring pengaman sosial (JPS). Pada tahun 1999, mulai terjadi recovery ekonomi dan pertumbuhan ekonomi mulai positif. Pada periode yang sama, pemerintah kembali mengambil stance kebijakan fiskal yang bersifat kontraktif yang terutama dilakukan melalui pengurangan alokasi anggaran belanja untuk subsidi dan JPS, karena dinilai kurang tepat sasaran. Pada tahun 2000, pertumbuhan ekonomi makin positif, namun stance kebijakan fiskal terlihat ekspansif. Namun, hal ini sebenarnya lebih disebabkan karena perubahan tahun anggaran dari fiskal menjadi kalender yang menyebabkan terjadinya dua kali akhir tahun anggaran. Berdasarkan pola musiman APBN, pengeluaran pemerintah pada triwulan terakhir tahun anggaran selalu jauh lebih besar dari tiga triwulan lainnya.

3. Pada tahun 2001 dan 2002, pertumbuhan ekonomi masih positif dan stance kebijakan fiskal bersifat kontraktif. Pada kedua tahun ini, pemerintah terlihat sangat mengendalikan anggaran belanja melalui penurunan tajam pada subsidi untuk menutup besarnya pembayaran bunga utang dalam negeri, meskipun di sisi lain mencoba memberikan stimulus bagi perekonomian melalui fasilitas perpajakan. Phase ini sering disebut juga sebagai phase konsolidasi fiskal untuk menjamin tercapainya kondisi fiskal yang sustainabel. 
4. Pada tahun 2003, pemerintah terlihat akan menjalankan kebijakan fiskal yang relatif netral dibandingkan tahun sebelumnya. ${ }^{10}$ Meskipun masih relatif terbatas, penurunan alokasi anggaran untuk subsidi dikompensasi dengan peningkatan alokasi anggaran untuk pengeluaran pembangunan, sejalan dengan meningkatnya tuntutan dari masyarakat dan DPR akan stimulus fiskal. Dari sisi sustainabilitas fiskal, langkah ini dimungkinkan karena mulai terbukanya ruang gerak pemerintah untuk melakukan ekspansi, sejalan dengan terus menurunnya rasio utang terhadap PDB dan mulai bergulirnya kebijakan pengelolaan utang seperti kebijakan reprofiling dan refinancing utang dalam negeri. ${ }^{11}$

5. Sebagaimana telah dibahas dalam tinjauan teoritis FI, secara teknis stance kebijakan fiskal juga dapat dijelaskan sebagai hasil dari perkembangan dua aspek anggaran yaitu diskresi pemerintah dan dan dampak automatic stabilizer anggaran dalam merespons aktivitas perekonomian. Diskresi pemerintah tercermin dari perubahan actual budget, sedangkan dampak automatic stabilizer anggaran tercermin dari perubahan cyclically neutral budget. Pada periode 1995 - 1997, perhitungan actual budget pada tiap-tiap tahun menunjukkan bahwa pemerintah menjalankan kebijakan anggaran yang relatif netral (Grafik 2). Namun, perhitungan cyclically neutral budget menunjukkan bahwa sesuai perkembangan ekonomi pemerintah seharusnya menjalankan kebijakan anggaran yang bersifat ekspansif pada

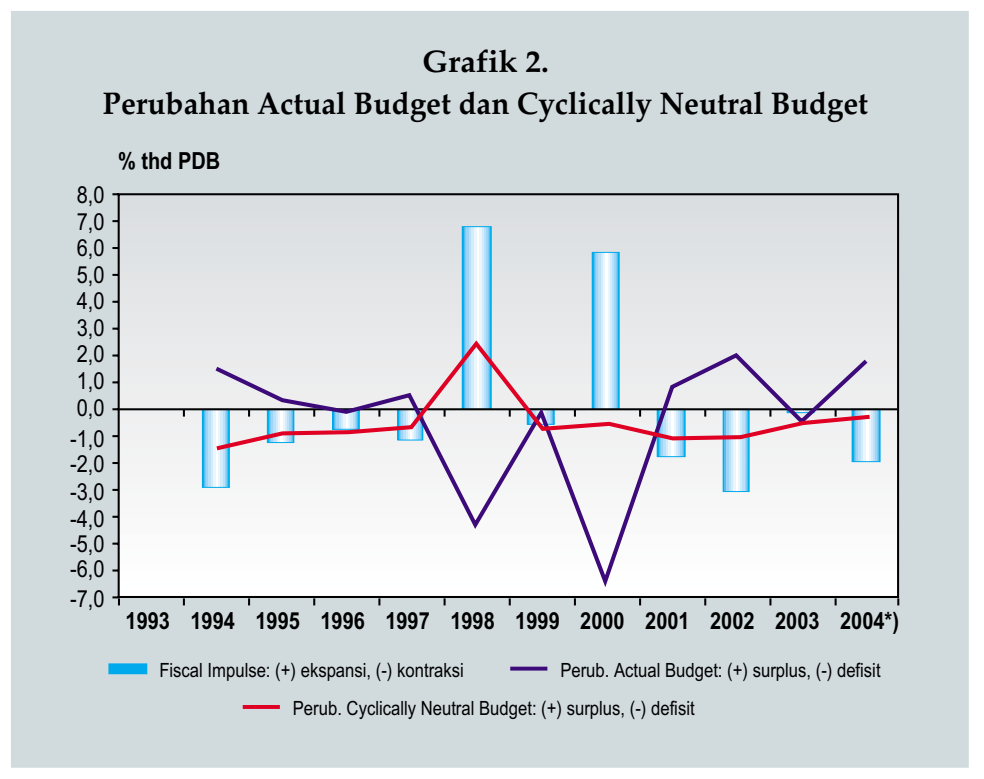

10 Jika mengacu pada konsep kategori stance kebijakan fiskal oleh Alesina dan Perotti (1995), stance pada tahun 2003 masih termasuk dalam kategori netral (-0,5\% s/d 0,5\% dari PDB).

11 Untuk pengujian sustainabilitas fiskal, lihat Decymus, Wahyu A. Nugroho, Bambang Kusmiarso dan T.M. Arief Macmud dalam "Kesinambungan Fiskal Indonesia Jangka Menengah, Program Kerja Strategis DKM, Bank Indonesia, 2001. 
tiap-tiap tahun tersebut. Dengan kata lain, diskresi anggaran yang ditetapkan pemerintah kurang longgar dibandingkan automatic stabilizernya. Pada kondisi demikian, dikatakan bahwa pemerintah menempuh stance kebijakan fiskal yang lebih kontraktif dibandingkan tahun sebelumnya.

6. Situasi yang hampir serupa juga terjadi pada tahun 1999, 2001, dan 2002. Pada tahuntahun tersebut pemerintah menempuh kebijakan fiskal yang bersifat netral dan kontraktif pada saat automatic stabilizer anggaran menunjukkan angka ekspansif. Situasi yang unik terjadi pada tahun 1998. Pada tahun tersebut, pemerintah justru melakukan menempuh kebijakan fiskal yang bersifat ekspansif pada saat automatic stabilizer anggaran memungkinkan pemerintah untuk menempuh kebijakan anggaran yang bersifat kontraktif. Pada kondisi ini, dikatakan bahwa pemerintah menempuh stance kebijakan fiskal yang lebih ekspansif dibandingkan tahun sebelumnya. Pada tahun 2003, pemerintah menempuh kebijakan fiskal bersifat netral yang ditunjukkan oleh angka actual budget yang hampir sama dengan cyclically neutral budget. Sementara itu, pada tahun 2004 pemerintah merencanakan untuk menempuh kebijakan yang kontraktif pada saat automatic stabilizer anggaran sebenarnya memungkinkan pemerintah untuk menempuh stance kebijakan yang netral.

\section{Penutup}

Pengukuran fiscal impulse ini harus dibedakan dengan pengukuran dampak rupiah operasi keuangan pemerintah. Pengukuran fiskal impulse lebih ditujukan untuk mengukur dampak bersih kontraksi dan injeksi fiskal terhadap PDB, sedangkan pengukuran dampak rupiah lebih ditujukan untuk mengukur dampak bersih seluruh kontraksi penerimaan (termasuk pembiayaan) rupiah dan ekspansi belanja rupiah pemerintah terhadap jumlah uang beredar. Dengan batasan tersebut, maka beberapa transaksi rupiah pemerintah yang diperhitungkan sebagai dampak rupiah APBN terhadap jumlah uang beredar seperti penerbitan utang dalam negeri dan amortisasi utang dalam negeri tidak termasuk dalam perhitungan fiscal impulse.

Pengukuran fiscal impulse dapat memperkaya metode konvensional yang biasa digunakan selama ini untuk mengukur dampak awal keuangan pemerintah terhadap sektor riil. ${ }^{12}$ Pengayaan tersebut adalah dalam bentuk dimasukkannya unsur pendapatan pajak

12 Metode konvensional untuk mengukur dampak awal operasi keuangan pemerintah terhadap sektor riil hanya didasarkan atas hubungan langsung antara pengeluaran konsumsi dan investasi pemerintah (atau PDB sektor pemerintah) terhadap PDB. Konsumsi pemerintah mencakup Belanja Pegawai Dalam Negeri, Belanja Barang Dalam Negeri, Sekitar $80 \%$ dari Dana Alokasi Umum (proksi), Dana Otonomi Khusus dan Penyeimbang, dan Pengeluaran Rutin Lainnya. Investasi pemerintah mencakup Pembiayaan Rupiah, Pembiayaan Proyek, Sekitar 20\% dari Dana Alokasi Umum (proksi), Dana 
dan penerimaan bukan pajak sebagai besaran fiskal yang bersifat mengkontraksi perekonomian dan dimasukkan unsur perkembangan PDB dalam perhitungan sehingga mampu mengidentifikasi ada tidak unsur diskresi atau upaya pemerintah untuk mempengaruhi permintaan agregat.

Pengukuran fiscal impulse pada dasarnya berguna untuk mengukur magnitude awal dari stimulus fiskal yang dilakukan pemerintah, namun tidak dimaksudkan untuk menghitung keseluruhan dampak (full impact) dari kebijakan fiskal terhadap permintaan agregat. Pengukuran keseluruhan dampak tersebut membutuhkan alat analisis lain yang mampu menghubungkan dampak kebijakan fiskal terhadap berbagai blok ekonomi lainnya dan terintegrasi dalam suatu bentuk macroeconometric model atau analisis input-output.

Bagi Hasil, dan Dana Alokasi Khusus. Sementara itu, Beban Bunga Utang Dalam Negeri dan Subsidi tidak termasuk dalam kedua kategori tersebut karena dianggap merupakan transfer payment sektor pemerintah ke sektor swasta yang nantinya akan mempengaruhi pembentukan PDB sektor swasta. 


\section{Referensi}

1. Macroeconomic Review, Monetary Authority of Singapore, January 2002.

2. N. Gregory Mankiw, Macroeconomics, Fourth Edition, 2000.

3. Peter Heller and others, A Review of the Fiscal Impulse Measure, IMF Occasional Paper No. 44, May 1986.

4. Renee Philip and John Janssen, Indicators of Fiscal Impulse for New Zealand, New Zealand Treasury Working Paper 02/30, December 2002.

5. Tom Clark and Andrew Dilnot, Measuring the UK Fiscal Stance since the Second World War, The Institute for Fiscal Studies, Briefing Note No. 26.

6. Decymus, Wahyu A. Nugroho, Bambang Kusmiarso dan T.M. Arief Macmud, Kesinambungan Fiskal Indonesia Jangka Menengah, Bank Indonesia, 2001. 